\title{
Revisiting Innovation Adoption Theory through Electronic Public Relations
}

Purpose: The purpose of the study is to shed light in the innovation adoption process taking place in the public relations field through the use of Web 2.0 applications and social network activities.

Design/methodology/approach: Innovation adoption of Electronic Public Relations (EPR) is examined at a personal, organizational and environmental level by employing for each one of the previous a number of different sub-dimensions leading to the creation and verification of a hierarchical tree structure.

Findings: E-pr innovation adoption can be influenced at a personal, organizational and environmental level. Each of the aforementioned levels are hierarchically linked to a number of factors that can actually speed up the process.

Originality/value: Never before to our knowledge the E-pr adoption process was examined as a hierarchical model bridging the innovation adoption literature with the public relations literature. 


\section{Revisiting Innovation Adoption Theory through Electronic Public Relations}

\section{INTRODUCTION}

Today, public relations activities take place at the center of an expanding highly dynamic digital media environment. The advent of social networks such as Facebook, Twitter, YouTube etc. in combination with the use of Web 2.0 applications (e.g., Berthon et al. 2012) both by public relations managers' and stakeholder publics has altered the way public relations is practiced, leading to the introduction of the term "electronic public relations" (E-PR). Although several studies point out the significance of electronic public relations in the business context (e.g.,Capriotti and Kuklinski 2012; Estanyol 2012; Kirat 2007; LaMarreand Suzuki - Lambrecht 2013; McAllister - Spooner 2009; Men and Tsai 2011; Sweetser and Kelleher 2011; Yang and Taylor 2010), only three papers (e.g., Alicilic and Atabek 2012; Kitchen and Panopoulos 2010; Robson and James 2011) have examined the adoption diffusion process in the public relations field. Moreover, there is a need to provide a holistic view of the adoption-diffusion process on a personal, organizational and environmental level. Given the fact that adoption diffusion precedes implementation, that the vast majority of the aforementioned studies research and determine the effectiveness of the use of E-PR, further investigation is mandated. Especially what is missing from the existing literature is an integrated theoretical framework specific to electronic public relations adoption and the conceptualization and measurement of factors affecting E-PR adoption.

Radical innovation is an unpredictable, sporadic, non-linear and stochastic phenomenon offering the potential of long-term superior performance and 
organizational renaissance (e.g., Leifer et al. 2001). However most innovations reported are classified as between not very new and substantially new, but not necessarily paradigm breaking (e.g., Sheremata 2004). As a result, radicality and/or compatibility with the previous non-innovative stage can be seen as a dichotomous flooding situation from incremental improvements to radical ones and potentially from perfect compatibility to incompatibility (e.g., Leifer et al. 2001). That is why many researchers (e.g., Damanpour and Evan 1984; Damanpour 1991; Kaplan 1999; Kinnunen 1996; Kitchell 1995; Dewar and Dutton 1986; Zaltmanet al. 1973; Garcia and Calatone 2002; Knight 1967; Zhou et al. 2005; Rogers 1995) conclude that innovation is any idea, practice or object that an adopting individual or organization perceives as 'new' and not as something that is totally pioneering. In the information technology (IT) domain according to the definition of Lee and Xia (2006) innovation can be defined as "an administrative or operational idea, practice or object, perceived as new by an organizational unit and whose underlying basis is IT". As a result information technology innovation can be of various types supporting technical tasks or deployed in a strategic way that may affect the overall organization (Zhu et al., 2003). According to Allen (2000) research in information technology is argued to be more an extension of organizational behavior and management than computer science since organizational structure, processes and people move IT innovations beyond what is usually described as purely technological.

The previous theoretical arguments can be extended for electronic public relations since they a) are supported by information technology developments b) require business and organization reconfiguration and c) can shape industry environments and stakeholder publics (Zhu et al., 2003). Most studies highlight the fact that public 
relations departments have distinctive and unique IT communication needs compared with other departments within the same company. With respect to strategic focus public relations departments are concerned with meeting the needs of stakeholder publics, cultivate relationships and create long-term profit. Thus much of the work of pr practitioners is about the exchange of information and communication. Their use of IT does not aim directly to a commercial benefit but to the improvement of the organization's ability to share ideas and information. As a result although use of social networks along with Web 2.0 applications can be considered mainstream in general this is not the case for public relations' purposes and activities (e.g., Estanyol 2012). This is particularly true for countries like Greece and the Balkan region in general since, according to credible reports from different sources (e.g., Eurostat 2013;2016; OECD 2013; EL.STAT. 2013),internet use and knowledge is still below the European Union average and international standards. Many organizations especially SME's do not perceive the need to integrate E-PR into their ongoing activities because of cost, time and lack of understanding of the full potential of E-PR and its strategic importance to their communication activities (Panopoulos, 2009).Thus when discussing the adoption of E-PR, Greek public relations' practitioners can be considered as laggards and their impact on the digital communication field can be seen as lower that its full potential (e.g.,Panopoulos, 2009).

Prior research (e.g., Carter Jr. et al. 2001; Kaplan 1999; Moore andBenbasat 1996; Harrison and Waite 2006; Thong 1999; Tornatzky et al.1990) indicate that the characteristics of the [technological] innovation, organizational and personal characteristics and the environmental context within it takes place, are the major determinants for the adoption of a technological innovation by an organization. The 
technological context here contains all the existing and emerging IT applications that can be used for public relations purposes, the organizational background includes the necessary resources and managerial support for the adoption of electronic public relations, personal characteristics refers to the capabilities and potentiality of public relations practitioners towards E-PR adoption and the environmental context describe the pressures facing by competitors and the stakeholder publics during the adoption process. At the same time over - hyped technologies, poor implementation and unintended consequences can offset technology innovation benefits (e.g., Murphy and Gomes 2003). As a result innovation should be treated as a complex cross-functional business process that requires integration of information from multiple disciplines (e.g., Montoya 2009). Here E-PR adoption is approached by juxtaposing and combining the innovation adoption literature with public relations and information technology theories.

It can be said that public relations practitioners today are in the midst of a learning curve (e.g., Toledano 2010) since the adoption of E-PR is a slow continuous process comprising an ongoing challenge and not just an isolated event. Social software tools like blogs, wikis, YouTube, Facebook, Twitter, Linkedin, MySpace and so on along with dynamic corporate websites and Web 2.0 applications such as Skype, videoconferencing, virtual worlds and games, provide powerful two-way symmetrical (Yang and Taylor, 2010) communication channels that can foster the egalitarian nature of dialogic relationships between the organizational stakeholder publics. The exchange of communication, interactions and experiences through E-PR can lead to the creation of social capital and to informational, psychological and instrumental benefits for all parties. 
The purpose of this paper is to shed light on E-PR adoption not by simply applying different adoption models and diffusion theories in the public relations field but by creating, through structural equation modeling, a new formative holistic model supporting E-PR's adoption process. Evidence from past innovation studies (e.g., Premkumar et al. 2008; Vallerand et al. 1997; Venkatesh 2000; Venkatesh and Speier 1999) have so far to our knowledge little emphasize on creating and testing multilevel adoption factors nor investigate these factors on the innovation adoption process. This study addresses the following research question: What are the factors on a personal, organizational and environmental level that influence the innovation adoption process of electronic public relations. Furthermore, the identification of personal, organizational and external environment constructs that influence the adoption process along with their subcomponents can serve as an instrument for the enhancement of E-PR diffusion and effectiveness, and enabling valuable theoretical and managerial insights. Finally, the paper will contribute to the general innovation adoption literature and to the use of IT applications for managerial communication purposes.

This paper is organized as follows: First the innovation literature is reviewed along with public relations' theories in an effort to accomplish a multi-disciplinary approach. Secondly the research methodology employed is described where the conceptualization and operationalization of the proposed E-PR adoption model takes place, followed by the statistical analysis and findings. We conclude the paper with the theoretical, empirical and managerial contributions to this important field.

\section{THEORETICAL BACKGROUND}


Since E-PR practice is bounded by social, economic and technological environs, it has been significantly affected by the exponential growth of the internet and the advent of new web 2.0 applications (e.g., Kitchen and Panopoulos 2010).A thorough examination of the innovation literature (e.g., Cascio et al 2010; Lynn et al. 2002; Pulkki-Brannstrom and Stoneman 2013; Schillewaert et al. 2005; Waarts et al. 2002) along with E-PR studies (e.g., Estayanol 2012; McAllister - Spooner 2009) form the basis of this research and reveals three major areas that underpin the diffusion process. More specifically the adoption of an innovation by an organization can be detected at an individual level (e.g., Chen et al. 2009; Gallivan 2003; Hameed et al. 2012; Lee and Kozar 2008; Leifer et al. 2001; Markati et al. 2008; Panopoulos and Sarri 2012; Schilling 1998; Schillewaert et al.2005) since it has to be implemented by people working for a company, at the organizational level (e.g., Camison and Lopez 2012; Damanpour and Schneider 2009; Hameed et al. 2012; Harrison and Waite 2006; Jeon et al. 2006; Lee and Xia 2006; Leifer et al. 2001; Mock and Morse 1977; Sharma and Ra 2003; Raymond 1985; Terlaak and Gong 2008; Wu et al. 2003) since it will eventually have to be embraced by the whole organization in order to succeed in the contextual environment(e.g., O'Neill et al. 1998; Chau and Tam 1997; Chwelos et al. 2001; Hamel and Mol 2008;Hameed and Counsell 2012; Harrison and Waite 2006; Lee and Xia 2006;Premkumarand Ramamurthy 1995; Quaddus and Hofmeyer 2007; Terlaak and Gong 2008; Wu et al. 2003) which itself is heavily influenced by the external developments. Therefore, we can hypothesize that: RP1: Electronic public relations adoption is a multidimensional, hierarchical construct incorporating the dimensions of Personal characteristics, Organizational characteristics and Environmental characteristics. 


\section{Personal Characteristics}

Opportunity recognition and the tendency to change depend heavily on individual initiatives, skills, competences and knowledge. Therefore executives with risk taking propensity, out of the box thinking and entrepreneurial behavior can be seen as catalysts for change (e.g., Schumpeter 1965). Regarding the personal characteristics that influence the innovation adoption process of E-PR, the literature (e.g., Panopoulos and Sarri2012; Schillewaert et al.2005) identifies computer self-efficacy, personal innovativeness, attitudes and perceptions towards the innovation. Technology competence requires not only physical assets but also intangible personal characteristics which are more likely to generate competitive advantages since skills and know how are complimentary to technological assets and difficult to obtain (Zhu et al., 2003). These factors are associated with the attributes of innovative individuals and (e.g., Becker1992), they can be seen as the basic psychological underpinnings of human capital in an organization. Computer self-efficacy, which refers to the extent of prior experience of[a] public relations' practitioner with computers and on-line environs, can create and enhance positive perceptions about E-PR (e.g., ShiversBlackwell and Charles 2006; Compeau and Higgins 1995; Venkatesh and Davis 1996). Self-efficacy theory is based on Bandura's work (1986) about the utilization of physical, intellectual and emotional resources required to deal with prospective situations. Computer self-efficacy depicts the prior level of knowledge that public relations' practitioners have in computer applications which can provide the foundation for and accelerate the development of E-PR activities. Personal innovativeness, or the persisting tendency of public relations managers to innovate (e.g., Stam and Staton 2010; Midgley and Dowling 1978; Steenkamp et al. 1999; Agarwal and Prasad1998; Kirton 2003; Leavitt and Walton 1975; Midgley and 
Dowling 1993), can also be a significant predictor of E-PR adoption (e.g., Schillewaert et al. 2005; Limayem et al., 2000; Frambach and Scillewaert, 2001). Personal innovativeness is defined according to Panopoulos and Sarri (2012) "as a predisposition or attitude describing an executive's learned and enduring cognitive evaluations, emotional feelings and action tendencies towards adopting new information technologies".

Attitudes and perceptions towards an innovation further determine the positive or negative behavior of an individual, according to several researchers (e.g., Premkumar et al. 2008; Vallerand et al. 1997; Venkatesh 2000; Venkatesh and Speier 1999). Motivation theory supports that attitudinal or behavioral beliefs can significantly affect the favorable outcome of an innovation adoption. Therefore, we can hypothesize that:

RP2: Personal characteristics as a construct incorporates Computer self-efficacy, Personal innovativeness, Attitudes and Perceptions of public relations practitioners towards the innovation.

\section{Organizational Characteristics}

Organizational characteristics include, the size of the organization and more specifically the number of employees, the number of practitioners in the public relations department and capitalization, top management support, technical support and training in order to overcome perceived obstacles, are reported in various adoption studies (e.g., Dholakia and Kshetri 2004; Laforet 2008; Lee and Xia 2006; Stock et al.2002) as predictors for innovation-adoption. Different types of IT innovation require different degrees of resource commitments because of their scope and complexity (Sharma \& Rai 2015). The capacity of an organization to have access 
both to human and capital resources can boost diffusion of an innovation (e.g., Dholakia and Kshetri 2004). Organization structure and innovative organizational forms therefore can help in exploring and exploiting new opportunities. Larger organizations in general are more receptive to initiate an innovation adoption procedure (e.g., Lee and Xia 2006; McKay et al. 2004; Hameed et al. 2012; Zhu et al., 2003), though according to the initial Schumpeterian hypothesis organizational size would be negatively correlated with innovation adoption. There are however few studies reporting that small and medium enterprises, due to the lack of bureaucratic procedures and their lean organizational structures can implement innovations faster (e.g., Laforet 2008). Since the majority of the studies in the literature lean towards a positive correlation in general towards size we decided to include that to RP3 in order to investigate it further in our case. Top management support is also a crucial factor for successful adoption (e.g., Cascio et al. 2010; Wu et al. 2003; Damanpour and Schneider 2009), since E-PR adoption should be treated as a strategic decision received by senior management. Top management has a central role in implementing strategic decisions (e.g., Kohli and Jaworski 1990) and as a result the strategic nature of electronic public relations' calls for an organization's communication plan (e.g., Hwang 2012) which requires top management attention and commitment. A combination of low levels of a) horizontal specialization, b) formalization, c) centralization and interdepartmental communication can increase flexibility, creativity, experimentation, freedom to act and greater interaction, providing a solid base for the adoption of an innovation (e.g., Camison and Lopez 2012). Finally, on the grounds that perceived obstacles are reported to have negative effects on IT innovation adoption efforts (e.g., Berthon et al. 2012; Hong and Zhu 2006; Panopoulos and Sarri 2012), it is important for an organization to provide the 
necessary training and constant technical/informational support to help overcome any reported problems.

RP3: The Size of an organization in terms of the number of employees, the number of public relations practitioner and capitalization, Top management support, the appropriate Training support and Technical support are the antecedents of the Organizational characteristics.

\section{Environmental Characteristics}

Since an organization is not an isolated unit but interacts with its external environment and society as a whole, it can be assumed that influences received from stakeholder publics and competitors will significantly affect the adoption process (e.g., Mckay et al. 2004; Panopoulos and Sarri 2012; Schillewaert et al. 2005; Zhu et al., 2003). According to the literature (e.g., Abrahamson and Rosenkopf 1993; DiMaggio and Powell 1983; Rogers, 1995) stakeholder publics and competitors can be seen as external change agents that influence the adoption diffusion process of an IT innovation. The adoption of a strategic innovation like E-PR can change the competition landscape, affect the business structure and leverage new ways to outperform rivals (Zhu et al., 2003). Stakeholder publics are the main receivers of EPR activities, while competitors also try to reach the same stakeholder publics through their potential E-PR actions, thus bringing pressure to bear for faster and more effective adoption. The phenomenon described above is strengthened by the fact that the use of social media and web 2.0 has turned stakeholder publics from content and message consumers to content and message providers (e.g., Berthon et al. 2012) allowing them to initiate and maintain communication procedures and thus increase the pressures towards an organization. That is why several innovations have been adopted by organizations on the basis of a 'bandwagon effect' or the need to keep up 
with environmental change and not by strategic choice. The bandwagon effect can be so strong that sometimes the phenomenon of the "blind leading the blind" results in the forced adoption of inefficient innovation out of fear that other organizations will use them successfully (e.g., O'Neill et al. 1998). This is particularly true for public relations departments since one of their main responsibilities is the continuous environmental scanning and communication adaptation to stakeholder publics (e.g., Chen 2013; Ramsey 1993). Thus we can propose that:

RP4: Environmental characteristics as a construct incorporate perceived pressures from stakeholder publics and perceived pressures from competitors.

Summing up according to the literature innovation adoption is a multi-disciplinary process affected by a number of factors at different levels. This study attempts to approach the innovation adoption in the public relations sector by examining the contribution of several variables and also at the same time by categorizing these variables in a personal organizational and environmental level, thus creating a hierarchical structure. Each of the four research propositions will be tackled via the method described below.

\section{METHODOLOGY}

After an extensive review of both the innovation and the public relations literature, an exploratory qualitative study was conducted. Three public relations academics, along with three highly experienced public relations practitioners, were interviewed and the outcomes were content analyzed using established qualitative data analysis techniques (e.g., Miles and Huberman 1994). This method allows the specification of construct domains, the generation of sample items for new constructs, the examination of the validity of existing and adapted measures, and the assessment of the 'nomological' 
validity of the conceptual model (e.g., Churchill 1979). In most cases, existing scales from the literature with modifications to fit the context of the study were used, as shown in Table 1 below.

Table 1

For each of the three major components - personal, organizational and environmental characteristics - subcomponents were added and finally individual items were specified. Based on these qualitative findings, a draft questionnaire was constructed and pre-tested with 12 public relations practitioners with experience in E-PR practices in order to check content validity (e.g., Fraenkel and Wallen2000). This process led to a modification of five items which were rephrased according to practitioners' suggestions.

The questionnaire was subsequently uploaded electronically. The targeted sample consisted of public relations practitioners employed by companies participating in the Athens Stock Exchange. Companies participating in the research derived from private or public sector covering a variety of activities (ex. technological, banking, construction etc) and with a wide size in terms of capitalization and human capital. An e-mail containing instructions and a 7-digit password was sent to each companies' public relations department. The electronic questionnaire can eliminate human mistakes in the data-entry level but because of the lack of human presence it can suffer in terms of correct completition by the respondents. In order to minimize potential coverage bias, we followed all the established protocols including creating awareness, providing securitized access to the research instrument, ease of navigability, and straightforward completion (e.g., Goldby et al. 2001; Solomon 2001). Out of 362 public relations practitioners, 119 responded by completing the 
electronic questionnaire creating a satisfactory response rate of $32.87 \%$ (e.g., Fraenkel and Wallen 2000) much higher than most electronic surveys (e.g., Solomon 2001). Further, in order to ensure that the sample size was appropriate, a mathematical formula was used ${ }^{1}$ (e.g., Newbold 1995). The result indicated that the desirable size of the sample should be 83 , which is less than the actual size of the sample.

Though with the previous mathematical formula used the size of the sample found appropriate we tried also to eliminate any possible bias of the characteristics of the population that participated in the research with those that chose not to do so. In order to do that we followed a well established procedure (e.g., Armstrong and Overton 1977; Fitzgerald and Fuller 1982; Lin and Schaeffer 1995; Groves and Peytcheva 2008) based on the differences (if any) between early and late respondents. According to the studies mentioned above there is a relationship between participating in a research and the speed of response allowing the equation of those that did not answer at all with those that answered with great delay. As a result two groups consisting of $20 \%$ of the research population coded as early and late respondents were created and checked for differences at 0.05 level. No statistical differences were found in the answers of these two groups and as a result, we can conclude that there was no significant difference between those that participated in this research and those that chose not to do so (e.g., Armstrong and Overton 1977; Fitzgerald and Fuller 1982; Lin and Schaeffer 1995). While all the criteria identified by Groves and Peytcheva (2008), such as survey length, respondent pre-notification, follow-up contacts, and issue salience (i.e. salience was defined as topic that dealt with an important issue (Martin, 1995) that was also current or timely) were catered for by our research design, a non-

$$
{ }_{1} n=\frac{N^{*} p(1-p)}{(N-1) \sigma_{p}^{2}+p(1-p)}
$$


probability sampling frame was used. Thus, the findings can only be projected to the obtained sample (Advisory Panel, 2009).

The construct of E-PR adoption was used instead of a discrete or dichotomous question about its adoption by practitioners as applied in some innovation studies (e.g., Schillewaert et al. 2005). The reason for doing so lies in the fact that such an approach is too narrow and does not cover the entire domain of true innovation adoption as a construct. The variation that is natural to exist in terms of the degree of adoption by the target population cannot be captured by a single item only.

\section{DATA ANALYSIS}

The majority of practitioners participating in this research were female $(58.4 \%)$ in their $31-35$ years old (32.7\%) holding a bachelor $(38.2 \%)$ or a master degree $(27.4 \%)$ with an average salary of 1000-1500 Euros(39.8\%) and 1-4 years of public relations' experience (37.1\%). These findings are in alignment with the demographics reported by previous researchers (e.g., Kitchen and Panopoulos 2010; Mywage.gr 2016).In general most of the companies in the Greek business sector have marketing departments with pr departments or positions reporting directly to them. As a result pr positions can be the entry level in the companies' marketing department.

The measurement model was first analyzed to test the reliability and validity of the instrument and then the structural model was analyzed to test the research hypotheses (e.g., Anderson and Gerbing, 1988). The first phase of data analysis refers to the examination of the proposed construct (Figure 1) in terms of examining the respective relationships at the various hierarchical levels. 
Figure 1. E-PR Adoption Construct

Since we did not expect all indicators to load on a single factor, Harman's single factor test that corroborates the absence of common method bias was used (e.g., Podsakoff et al. 2003). Moreover in order to be certain that common method bias was not an issue - in addition to the above step - the procedure described by Liang et al. (2007) was adopted i.e. we added a common method factor in the structural model whose indicators included all the principal constructs' indicators and calculated each indicator's variances substantively explained by the principal construct and by the method factor (Liang et al., 2007). Evidence of common method bias can be obtained by examining the statistical significance of factor loadings of the method factor and comparing the variances of each observed indicator explained by its substantive construct and the method factor (Williams et al., 2003). Results demonstrated a small magnitude of method variance as well as principal variable loadings were all significant at 0.001 level, while none of the common method factor loadings were found significant, we contend that the method bias is unlikely to be a serious concern for this study.

Having in mind the items employed in order to measure the nine sub-dimensions of the three major components of E-PR adoption, the examination has been focused on the degree of their fit with the respective sub-dimensions, for which each item was thought to fit. The CFA procedure reveals that the items indeed fit well with the respective sub-dimension for which they have been pertained to be (Table 2). Moreover, almost all the sub-dimensions are correlated with those sub-dimensions have been designed to correlate according to the notion of the construct and showed their consistency as indicated by Cronbach's alpha coefficient. 
Next in the analysis, nine new variables (summated means) were developed in order to represent each of the nine sub-dimensions. The three major dimensions i.e. Personal Characteristics, Organizational Characteristics and Environmental Characteristics were examined for convergent and discriminant validity (Table 3). Surprisingly, the coefficient estimate of the sub-dimension Size was not significant, leading to its exclusion from further analysis.

Evidence of discriminant validity is provided by a low to moderate correlation among measures when are designed to measure conceptually different but related constructs: a value of a phi $(\varphi)$ coefficient significantly less than one offers support for discriminant validity among the constructs (Anderson and Gerbing, 1988). The interfactor correlation $(\varphi)$ estimates for all the three dimensions were lower than 1. According Fornell and Larcker (1981) a construct is empirically distinct if the average variance (AVE) explained by that construct's items is greater than the construct's shared variance with every other construct i.e. the square of the inter-factor correlations between any two constructs $\left(\varphi^{2}\right)$ (Table3).

Further, it is crucial to examine the reliability of the proposed models and especially composite reliabilities and the variance extracted values (e.g., Hair et al., 1998). Composite reliability refers to a principle measure in assessing measurement models (e.g., Fornell and Larcker; 1981; Hair et al. 1998). It is a complementary measure to the construct reliability and evidence of internal stability and convergent validity (e.g., Fornell and Larcker, 1981). It is worth mentioning that higher values of variance extracted take place when the indicators are certainly demonstrative of the latent construct. The composite reliabilities and the values of variance extracted are 
presented in Table 3. All the three models of the three major dimensions present evidence of composite reliability (Table3).

In fact, E-pr adoption is a multidimensional, hierarchical construct (Figure 1) and thus it is crucial to examine whether this multi level factor model fits in an appropriate manner the specific data. For this reason two levels of the specific model were further examined.

Firstly, the three major dimensions are evaluated to be indicators of the E-pr Adoption construct i.e. a second order factor model with E-pr Adoption -second order factorPersonal, Organizational and Environmental characteristics as latent variables -first order factors- and their eight sub-dimensions as items (summated means). Adopting structural equation analysis and a CFA procedure, the relative statistics indicate (Table 3 ) that the model fits the data relative well $(\mathrm{GFI}=0.83 ; \mathrm{AGFI}=0.78 ; \mathrm{CFI}=0.81$, RMSEA=0.078). Then, the CFA procedure regarding the three major dimensions showed appropriate behavior to the sample data (Table 4). In this case, the E-pr Adoption was represented as a latent variable with the three major dimensions as indicators (first order factor model). The analysis neglected the step where the three major dimensions as latent variables could be freely correlate each other having as indicators their sub-dimensions, since there is no evidence in the literature supporting that Personal, Organizational and Environmental Characteristics have a degree or a form of association. The results of the aforementioned analysis indicate a strong support of all four research propositions, except the case of the sub-dimension Size which found to be non significant in its participation to the major dimension of Organizational Characteristics. 


\section{DISCUSSION}

The results of the study verify the three major factors that determine the diffusion process reported in the innovation literature (e.g., Carter Jr. et al. 2001; Harrison and Waite 2006; Kaplan 1999; Moore and Benbasat 1996;Thong 1999; Tornatzky et al. 1990). The electronic public relations adoption rate is influenced by personal, organizational and external level elements, thus RP1 was verified. As a result, the combination of individual characteristics and skills, organizational resources and decisions, stakeholder publics' demands and competitors' activities can each impact upon and determine E-PR adoption rates. The identification of individual characteristics along with the organizational characteristics and the environmental influences bridges the dominant macro-level focus of previous organizational level studies and the dominant micro-level focus of individual level studies on innovation adoption in general but also on E-PR adoption.

Computer self-efficacy, training and technical support verify that the technological nature of E-PR should be taken into serious consideration during the adoption process. Computer self-efficacy should be a mandated skill for public relations practitioners when engaging in digital activities. By saying that we do not imply that public relations practitioners are expected to act as IT professionals but they ought to have basic knowledge in computer operation which can be seen as a solid ground to build upon and expand. Any gaps or lack of knowledge in the use of digital applications for public relations issues are expected to be covered through training programs implemented by an organization. By doing so, public relations practitioners will strengthen their IT background, accelerate the adoption of E-PR, and be able to use it more effectively. Perhaps they can also perceive the existence of training as an 
additional sign that the organization supports and encourages the adoption of E-PR.

Though computer self-efficacy and training can empower public relations

practitioners in order to face the digital challenges ahead of them this still is not

enough since several obstacles of a technical nature are reported from different

innovation studies (e.g., Dholakia and Kshetri 2004; Laforet 2008; Lee and Xia 2006;

Panopoulos and Sarri 2012; Stock et al.2002; Kitchen and Panopoulos 2010;

Schillewaert et al. 2005). This is why professional technical support is required especially when IT problems arise. Since the internet, as the communication medium, forms the backbone of E-PR it is possible that certain technical problems, beyond the capabilities of public relations practitioners, appear. Perhaps a close cooperation with the IT department within the organization can help public relations practitioners overcome any IT dysfunctionality exercise greater confidence in using digital communication applications.

Pressures from the external environmental characteristics reveal the egalitarian twoway symmetrical nature of E-PR practices (e.g., Alikilic and Atabek 2012; Guiniven 2002; Theunissen and Noordin 2012) and their impact on the adoption process. The increasing use of social media and Web 2.0 applications by stakeholder publics enables them not to act as passive viewers and wait from organizations to decide when and how they will transmit their messages but instead stakeholder publics can initiate and escalate the communication process, without being controlled, creating effective electronic word-of-mouth (e.g., Keller and Kitchen 2014). At the same time firms are benefiting from the customer engagement and can perform more effective communication since they have the ability to mine and analyze customer data more effectively and personalize marketing activities based on customer interests. Needless 
to say that competitors, since everything in the digital world moves faster than in the physical world, participating in this exchange of communication strengthening their relations with stakeholder publics will result in competitive advantage (e.g., Kitchen and Uzunogu 2014). As mentioned earlier, the above situation can exercise pressure on public relations practitioners to engage in a me-too situation, triggering a bandwagon effect which is not necessarily sound. Yet, according to Darwin (Johnson et al. 2013) "the process of adaptation by natural selection can apply to any interacting agent biological or not" so when your environment changes significantly like the digital environment does, you have two choices either adapt or face extinction.

Top management support, personal innovativeness and attitudes and perceptions towards the innovation influence E-PR adoption and should be carefully examined managerially. Knowing the personal characteristics that public relations practitioners should have along with the organizational support they should get, can help the organization develop, initiate and implement effective E-PR relations. Since E-PR adoption besides the underlying technological nature that it has should actually be seen as a managerial novelty it is important to have full top management support. Knowing that E-PR adoption is a strategic decision and that its importance is fully recognized and supported by senior management is a major spur for public relations practitioners to try harder and adopt E-PR more rapidly. At the same time, employing public relations practitioners that believe in the advantages and the necessity to adopt E-PR can be important as they generally are receptive to different innovations in their personal life or at work, and thus may act as change agents by giving a significant boost to the innovation adoption procedure. 
Finally the exclusion of size as a sub-dimension verifies the mixed results reported in the literature (e.g., Hameed et al. 2012; Lee and Xia 2006) though it should be mentioned that the size of Greek companies has been severely affected by the sudden economic crises in the market. A possible explanation for the exclusion of size may be sought at the fact that the initial cost and resources needed in order to initiate any electronic activity is generally low (e.g., Hong and Zhu 2006; Venus andQuaddus2011) while electronic communication is not consider to be an intensive labor activity.

\section{CONCLUSIONS}

\section{Theoretical Implications}

The theoretical contribution of this paper is of a dual nature as implications apply both to the innovation and the public relations literature. The framework developed can be applied by other researchers for further studies in E-PR or other information technology adoptions in different settings. From a public relations perspective it is the first time that a holistic approach deviating from the usual adoption models like TAM, TRA, IDT, and Rogers has been tested with empirical data leading to the creation of a customized adoption instrument for E-PR (Figure 1). Furthermore, the model developed enables the investigation of critical factors affecting electronic public relations at the adoption level offering answers to issues encountered by other studies (e.g., Estayanol 2012; Toledano 2010; Men and Tsai 2011; Sweetser and Kelleher 2011; Yang and Taylor 2010) at the implementation level. For example the questions raised about proper and effective use of E-PR activities, the preparation and the need of such activities can be addressed and resolved to some extent at the diffusion level. At the same time the model may enrich the innovation literature by verifying the influence of innovation adoption at an individual, organizational and environmental 
level as suggested by RP1. Going one step further it acknowledges the specific factors underlying each of the above mentioned dimensions encouraging further studies with the use of this approach. As a result personal innovativeness, computer self-efficacy and attitudes and perceptions of individuals toward the innovation form the personal characteristic construct and significantly affect the rate of adoption verifying RP2. A combination of computer knowledge, positive perceptions and the tendency to innovate in everyday life can boost the diffusion of an IT innovation at a personal level giving to people the necessary material to implement change. Since innovation in an organization is hardly a personal matter, management support is needed along with technological support and training especially when an IT innovation occurs. The size of the organization does not affect the adoption process verifying the outcome of the meta-analysis on IT innovation by Hameed et al. (2012) that reported mixed results in terms of size, leading to a partial support of RP3. Finally environmental characteristics as expressed through the perceived pressures exercised by both competitors and publics can also act as a proxy for innovation adoption since monitoring what a companies' competitors do and what their target audience wants in terms of an innovation can lead to a bandwagon effect.

\section{Managerial Implications}

From a managerial point of view practical insights can be offered to public relations managers and organizations. As internet technologies diffuse and become necessities technical and managerial knowledge for the E-PR environment becomes even more significant an implication consistent with recent E-PR studies (McAllister - Spooner 2009; Men and Tsai 2011; Sweetser and Kelleher 2011; Yang and Taylor 2010). This urges top managers to foster managerial skills and human resource that processes the knowledge of E-PR and reminds communication departments to develop training 
programs. Prior knowledge in computer and internet use should be required as an additional qualification when recruiting public relations practitioners that will activate in digital environs. However this does not mean that public relations practitioners should have an IT background or be professional in IT. That is why assistance from other departments at an organizational level, for example from the IT department, should be offered when obstacles are encountered. But managers can also act proactively, and even if no IT problems reported, they should try to empower the internet skills of their practitioners through training programs. Deviations from the individual characteristics reported reveal the elements that are in opposition to adoption thus require managerial intervention to achieve alignment and increase the odds of adoption. Furthermore they should demonstrate their personal support towards the adoption and implementation of E-PR if they wish others to effectively adopt it. External pressures should also be taken under consideration and carefully handled. Monitoring public and competitors attitudes as far as the use of electronic public relations is concerned can help acknowledging the need to adjust to the challenges of the new digitally empowered communication world. Finally the encouragement of positive attitudes and perceptions towards an innovation as well as the cultivation of personal innovativeness by allowing the employment with other IT innovations and actions can positively affect the rate of E-PR adoption. Since in many organizations a ban towards the use of social media and web 2.0 applications among employees is reported, senior management should reconsider that policy for the public relations department.

\section{Limitations - Future Research}


The outcome of the study is limited by the cultural environment of the sample since it is only tested in the Greek business context (thus there could be a case of potential bias), during a specific period of time so it cannot be projected in the future or compared to the adoption process of E-PR in other countries or in other business sectors. According to studies a relationship between cultural norms and values and the adoption of social media across different countries exists (e.g., Berthon et al. 2012). Moreover, since the E-PR function and public relations practitioners were examined without taking into consideration the possible interactions with other functions or departments of an organization, the results can only be projected to the public relations' sector. Future studies should test:

$>$ the proposed instrument on the global adoption of E-PR

$>$ the adoption process of E-PR practices by stakeholder publics since they are the main target of E-PR activities

$>$ the connection of E-PR adoption and E-PR effectiveness

>the implementation of a longitudinal approach in order to shed light to the evolution of E-PR adoption through time and finally,

$>$ further refinement of the conceptual model as innovation continues apace.

\section{References}

Abdul Hameed, M., \& Counsell, S. (2012). Assessing the influence of environmental and CEO characteristics for adoption of information technology in organizations. Journal of technology management \& innovation, 7(1), 64-84.

Ajzen, I., and Fishbein, M. (1969).The prediction of behavioural intentions in a choice situation," Journal of Experimental Social Psychology 5(4), 400-416. 
Alikilic, O., \& Atabek, U. (2012). Social media adoption among Turkish public relations professionals: A survey of practitioners. Public Relations Review,38(1), $56-63$.

Allen, J.P. (2000). Information Systems as technological innovation. Information Technology \& People, 13(3), 210-221.

Anderson, J. C., \& Gerbing, D. W. (1988). Structural equation modeling in practice: A review and recommended two-step approach. Psychological bulletin, 103(3), 411.

Agarwal, R., \& Prasad, J. (1998). The antecedents and consequents of user perceptions in information technology adoption. Decision support systems,22(1), $15-29$.

Armstrong, J. S., \& Overton, T. S. (1977). Estimating nonresponse bias in mail surveys. Journal of marketing research, 396-402.

Berthon, P. R., Pitt, L. F., Plangger, K., \& Shapiro, D. (2012). Marketing meets Web 2.0, social media, and creative consumers: Implications for international marketing strategy. Business horizons, 55(3), 261-271.

Camisón, C., \& Villar-López, A. (2012). On how firms located in an industrial district profit from knowledge spillovers: Adoption of an organic structure and innovation capabilities. British journal of management, 23(3), 361-382.

Capriotti, P., \& Kuklinski, H. P. (2012). Assessing dialogic communication through the Internet in Spanish museums. Public Relations Review, 38(4), 619-626.

Carter, F. J., Jambulingam, T., Gupta, V. K., \& Melone, N. (2001). Technological innovations: a framework for communicating diffusion effects. Information\& Management, 38(5), 277-287. 
Cascio, R., Mariadoss, B. J., \& Mouri, N. (2010). The impact of management commitment alignment on salespersons' adoption of sales force automation technologies: An empirical investigation. Industrial Marketing Management,39(7), 1088-1096.

Chau, P. Y., \& Tam, K. Y. (1997). Factors affecting the adoption of open systems: an exploratory study. MIS Quarterly, 1-24.

Chen, Y. S., Lin, M. J. J., \& Chang, C. H. (2009). The positive effects of relationship learning and absorptive capacity on innovation performance and competitive advantage in industrial markets. Industrial Marketing Management,38(2), 152-158.

Churchill Jr, G. A. (1979). A paradigm for developing better measures of marketing constructs. Journal of marketing research, 64-73.

Chwelos, P., Benbasat, I., \& Dexter, A. S. (2001). Research report: Empirical test of an EDI adoption model. Information systems research, 12(3), 304-321.

Compeau, D. R., \& Higgins, C. A. (1995). Computer self-efficacy: Development of a measure and initial test. MIS quarterly, 189-211.

Damanpour, F. (1991). Organizational innovation: A meta-analysis of effects of determinants and moderators. Academy of management journal, 34(3), 555-590.

Damanpour, F., \& Evan, W. M. (1984). Organizational innovation and performance: the problem of" organizational lag". Administrative science quarterly, 392-409.

Damanpour, F., \& Schneider, M. (2009). Characteristics of innovation and innovation adoption in public organizations: Assessing the role of managers.Journal of public administration research and theory, 19(3), 495-522.

Damanpour, F., \& Schneider, M. (2009). Characteristics of innovation and innovation adoption in public organizations: Assessing the role of managers.Journal of public administration research and theory, 19(3), 495-522. 
Dholakia, R. R., \&Kshetri, N. (2004). Factors impacting the adoption of the Internet among SMEs. Small Business Economics, 23(4), 311-322.

EL.STAT, (2013).

"Internet UsageandKnowledge,"http://www.statistics.gr/portal/page/portal/ESYE

Estanyol, E. (2012). Marketing, public relations, and how Web 2.0 is changing their relationship: A qualitative assessment of $\mathrm{PR}$ consultancies operating in Spain. Public Relations Review, 38(5), 831-837.

Eurostat, (2013). "Three quarters of Europeans used the Internet in 2013,’http://epp.eurostat.ec.europa.eu/portal/page/portal/eurostat/home/

Eurostat, (2016). Digital economy and society statistics - households and individuals http://ec.europa.eu/eurostat/statisticsexplained/index.php/Digital_economy_and_society_statistics__households_and_individuals

Fitzgerald, R., \& Fuller, L. (1982). I Hear You Knocking But You Can't Come In The Effects of Reluctant Respondents and Refusers on Sample Survey Estimates. Sociological Methods \& Research, 11(1), 3-32.

Fornell, C., \& Larcker, D. F. (1981). Evaluating structural equation models with unobservable variables and measurement error. Journal of marketing research, $39-50$.

Fraenkel, J. R., \& Wallen, N. E. (2000). How to design and evaluate research in education New York: McGraw.

Garcia, R., \& Calantone, R. (2002). A critical look at technological innovation typology and innovativeness terminology: a literature review. Journal of product innovation management, 19(2), 110-132. 
Goldby, T. J., Stank, T. P., \& Vickery, S. K. (2001). Web-based surveys: Reaching potential respondents on-line. DECISION SCIENCES, 32(2), 4-6.

Groves, R. M., \&Peytcheva, E. (2008). The impact of nonresponse rates on nonresponse bias a meta-analysis. Public opinion quarterly, 72(2), 167-189.

Hair, J. F., Black, W. C., Babin, B. J., Anderson, R. E., \& Tatham, R. L. (2006). Multivariate data analysis (Vol. 6). Upper Saddle River, NJ: Pearson Prentice Hall.

Hameed, M. A., Counsell, S., \& Swift, S. (2012). A conceptual model for the process of IT innovation adoption in organizations. Journal of Engineering and Technology Management, 29(3), 358-390.

Hameed, M. A., Counsell, S., \& Swift, S. (2012). A meta-analysis of relationships between organizational characteristics and IT innovation adoption in organizations. Information \& management, 49(5), 218-232.

Harrison, T., \& Waite, K. (2006). A time-based assessment of the influences, uses and benefits of intermediary website adoption. Information \& management, 43(8), 1002-1013.

Hulland, J., \& Richard Ivey School of Business. (1999). Use of partial least squares (PLS) in strategic management research: A review of four recent studies. Strategic management journal, 20(2), 195-204.

Johnson, D.P., Price, M., \&Vugt, M. (2013). Darwin's invisible hand: Market competition, evolution and the firm. Journal of Economic Behavior and Organization, 90, 128-140.

Jeon, B. N., Han, K. S., \& Lee, M. J. (2006). Determining factors for the adoption of e-business: the case of SMEs in Korea. Applied Economics,38(16), 1905-1916. 
Kaplan, S. M. (1999). Discontinuous innovation and the growth paradox.Strategy\& leadership, 27(2), 16-21.

Kaplan, A. W. (1999). From passive to active about solar electricity: innovation decision process and photovoltaic interest generation. Technovation, 19(8), 467481.

Kinnunen, J. (1996). Gabriel Tarde as a founding father of innovation diffusion research. Acta sociologica, 39(4), 431-442.

Kitchell, S. (1995). Corporate culture, environmental adaptation, and innovation adoption: a qualitative/quantitative approach. Journal of the Academy of Marketing Science, 23(3), 195-205.

Kitchen, P. J., \& Panopoulos, A. (2010). Online public relations: The adoption process and innovation challenge, a Greek example. Public Relations Review,36(3), 222-229.

Kirat, M. (2007). Promoting online media relations: Public relations departments' use of Internet in the UAE. Public Relations Review, 33(2), 166-174.

Knight, K. E. (1967). A descriptive model of the intra-firm innovation process.The journal of Business, 40(4), 478-496.

Laforet, S. (2008). Size, strategic, and market orientation affects on innovation. Journal of business Research, 61(7), 753-764.

LaMarre, H. L., \& Suzuki-Lambrecht, Y. (2013). Tweeting democracy? Examining Twitter as an online public relations strategy for congressional campaigns'. Public Relations Review, 39(4), 360-368.

Lee, G., \& Xia, W. (2006). Organizational size and IT innovation adoption: A metaanalysis. Information \& Management, 43(8), 975-985. 
Lee, Y., \& Kozar, K. A. (2008). An empirical investigation of anti-spyware software adoption: A multitheoretical perspective. Information \& Management,45(2), 109119.

Leifer, R., O'Connor, G. C., \& Rice, M. (2001). Implementing radical innovation in mature firms: The role of hubs. The Academy of Management Executive,15(3), 102-113.

Liang, H., Saraf, N., Hu, Q., \&Xue, Y. (2007). Assimilation of enterprise systems: the effect of institutional pressures and the mediating role of top management. MIS Quarterly, 31(1), 59-87.

Lin, I. F., \& Schaeffer, N. C. (1995). Using survey participants to estimate the impact of nonparticipation. Public Opinion Quarterly, 59(2), 236-258.

Lynn, G. S., Lipp, S. M., Akgün, A. E., \& Cortez, A. (2002). Factors impacting the adoption and effectiveness of the world wide web in marketing. Industrial Marketing Management, 31(1), 35-49.

MacKay, N., Parent, M., \& Gemino A. (2004). A model of electronic commerce adoption by small voluntary organizations. European Journal of Information Systems, 13, 147-159.

Marcati, A., Guido, G., \& Peluso, A. M. (2008). The role of SME entrepreneurs' innovativeness and personality in the adoption of innovations. Research Policy,37(9), 1579-1590.

Martin, C. L. (1994). The impact of topic interest on mail survey response behavior. Journal of the Market Research Society, 36(4), 327-337.

McAllister-Spooner, S. M. (2009). Fulfilling the dialogic promise: A ten-year reflective survey on dialogic Internet principles. Public Relations Review, 35(3), 320-322. 
Men, L. R., \& Tsai, W. H. S. (2013). Beyond liking or following: Understanding public engagement on social networking sites in China. Public Relations Review, 39(1), 13-22.

Miles, M. B., \& Huberman, A. M. (1994). Qualitative data analysis: An expanded sourcebook. Sage.

Moch, M. K., \& Morse, E. V. (1977). Size, centralization and organizational adoption of innovations. American Sociological Review, 716-725.

Montoya, M. (2009). A personal reflection on MSU contributions to innovation/new products. Michigan State University Contributions to International Business and Innovation, 15.

Moore, G. C., \&Benbasat, I. (1996). Integrating diffusion of innovations and theory of reasoned action models to predict utilization of information technology by endusers. In Diffusion and adoption of information technology (pp. 132-146). Springer US.

Murphy, J., \& Gomes, L. (2003). E-mail customer service by Australian educational institutions. Australasian Marketing Journal (AMJ), 11(2), 56-69.

Mywage.gr (2016). Average wage for pr practitioners.
http://www.mywage.gr/home/salary/elegkhos-misthou?job-id=2432010000000\#/ OECD, (2013). “OECD Internet Economy Outlook,” http://www.oecd.org/

O'Neill, H. M., Pouder, R. W., \&Buchholtz, A. K. (1998). Patterns in the diffusion of strategies across organizations: Insights from the innovation diffusion literature. Academy of Management Review, 23(1), 98-114.

Panel, A. (2009). Standards and guidelines for success rate. The Advisory Panel on Online Public Opinion Survey Quality, Marketing Research and Intelligence Association, Canada. 
Panopoulos, A. 2009. "Facing Electronic Public Relations as an Innovative Challenge,"14th International Corporate and Marketing Communications Conference (CMC), Cyprus, April 23-24.

Panopoulos, A. P., \&Sarri, K. (2013). E-mentoring: The adoption process and innovation challenge. International Journal of Information Management, 33(1), 217-226.

Podsakoff, P. M., MacKenzie, S. B., Lee, J. Y., \&Podsakoff, N. P. (2003). Common method biases in behavioral research: a critical review of the literature and recommended remedies. Journal of applied psychology, 88(5), 879.

Pulkki-Brannstrom, A.M. \& Stoneman P. (2013). On the patterns and determinants of the global diffusion of new technologies. Research Policy, 42(10), 1768-1779.

Robson, P., and James M. (2012). Trialling PR 2.0: an exploratory study of the noncapital city practitioner's social media use, The Asia Pacific Public Relations Journal 13(1), 19-40.

Rogers, E. (1995). Diffusions of innovations New York,Free Press, NY.

Schillewaert, N., Ahearne, M. J., Frambach, R. T., \&Moenaert, R. K. (2005). The adoption of information technology in the sales force. Industrial Marketing Management, 34(4), 323-336.

Schilling, M. A. (2002). Technology success and failure in winner-take-all markets: The impact of learning orientation, timing, and network externalities.Academy of Management Journal, 45(2), 387-398.

Sharma, S., \& Rai, A. (2003). An assessment of the relationship between ISD leadership characteristics and IS innovation adoption in organizations.Information \& Management, 40(5), 391-401. 
Sharma, S., \& Rai, A. (2015). Adopting IS process innovation in organizations: the role of IS leader's individual factors and technology perceptions in decision making. European Journal of Information Systems, 24, 23-37.

Sheremata, W. A. (2004). Competing through innovation in network markets: Strategies for challengers. Academy of Management Review, 29(3), 359-377.

Solomon, D. J. (2001). Conducting Web-Based Surveys. ERIC Digest.

Stam, K.R., \& Stanton, J.M. (2010). Events emotions and technology: examiningacceptance of workplace technology changes. Information Technology \& People, 23(1), 23-53.

Stock, G. N., Greis, N. P., \& Fischer, W. A. (2002). Firm size and dynamic technological innovation. Technovation, 22(9), 537-549.

Sweetser, K. D., \& Kelleher, T. (2011). A survey of social media use, motivation and leadership among public relations practitioners. Public Relations Review, 37(4), $425-428$.

Terlaak, A., \& Gong, Y. (2008). Vicarious learning and inferential accuracy in adoption processes. Academy of Management Review, 33(4), 846-868.

Thong, J. Y. (1999). An integrated model of information systems adoption in small businesses. Journal of management information systems, 15(4), 187-214.

Toledano, M. (2010). Professional competition and cooperation in the digital age: A pilot study of New Zealand practitioners. Public Relations Review, 36(3), 230237.

Tornatzky, L. G., Eveland, J. D., and Fleischer, M. (1990). Technological Innovation: Definitions and Perspectives, in The Processes of Technological Innovation, L. G. Tornatzky and M. Fleischer (eds.), Lexington, MA: Lexington Books, 9-25. 
Yang, A., \& Taylor, M. (2010). Relationship-building by Chinese ENGOs' websites: Education, not activation. Public Relations Review, 36(4), 342-351.

Venkatesh, V., \& Davis, F. D. (1996). A model of the antecedents of perceived ease of use: Development and test*. Decision sciences, 27(3), 451-481.

Waarts, E., Everdingen, Y. M., \&Hillegersberg, J. (2002). The dynamics of factors affecting the adoption of innovations. Journal of Product Innovation Management, 19(6), 412-423.

Williams, L. J., Edwards, J. R., \& Vandenberg, R. J. (2003). Recent advances in causal modeling methods for organizational and management research. Journal of Management, 29(6), 903-936 in Liang, H., Saraf, N., Hu, Q., \& Xue, Y. (2007). Assimilation of enterprise systems: the effect of institutional pressures and the mediating role of top management. MIS Quarterly, 31(1), 59-87.

Wu, F., Mahajan, V., \&Balasubramanian, S. (2003). An analysis of e-business adoption and its impact on business performance. Journal of the Academy of Marketing Science, 31(4), 425-447.

Zaltman, G., Duncan, R., and Holbek, J. (1973). Innovations and organizations, London: Wiley and Sons.

Zhou, K. Z., Yim, C. K., \&Tse, D. K. (2005). The effects of strategic orientations on technology-and market-based breakthrough innovations. Journal of marketing, 69(2), 42-60.

Zhu, K., Kraemer, K., and Xu, S. 2003. “Electronic business adoption by European firms: a cross-country assessment of the facilitators and inhibitors.", European Journal of Information Systems 12, 251-268. 


\section{Figure 1. E-PR Adoption Construct}

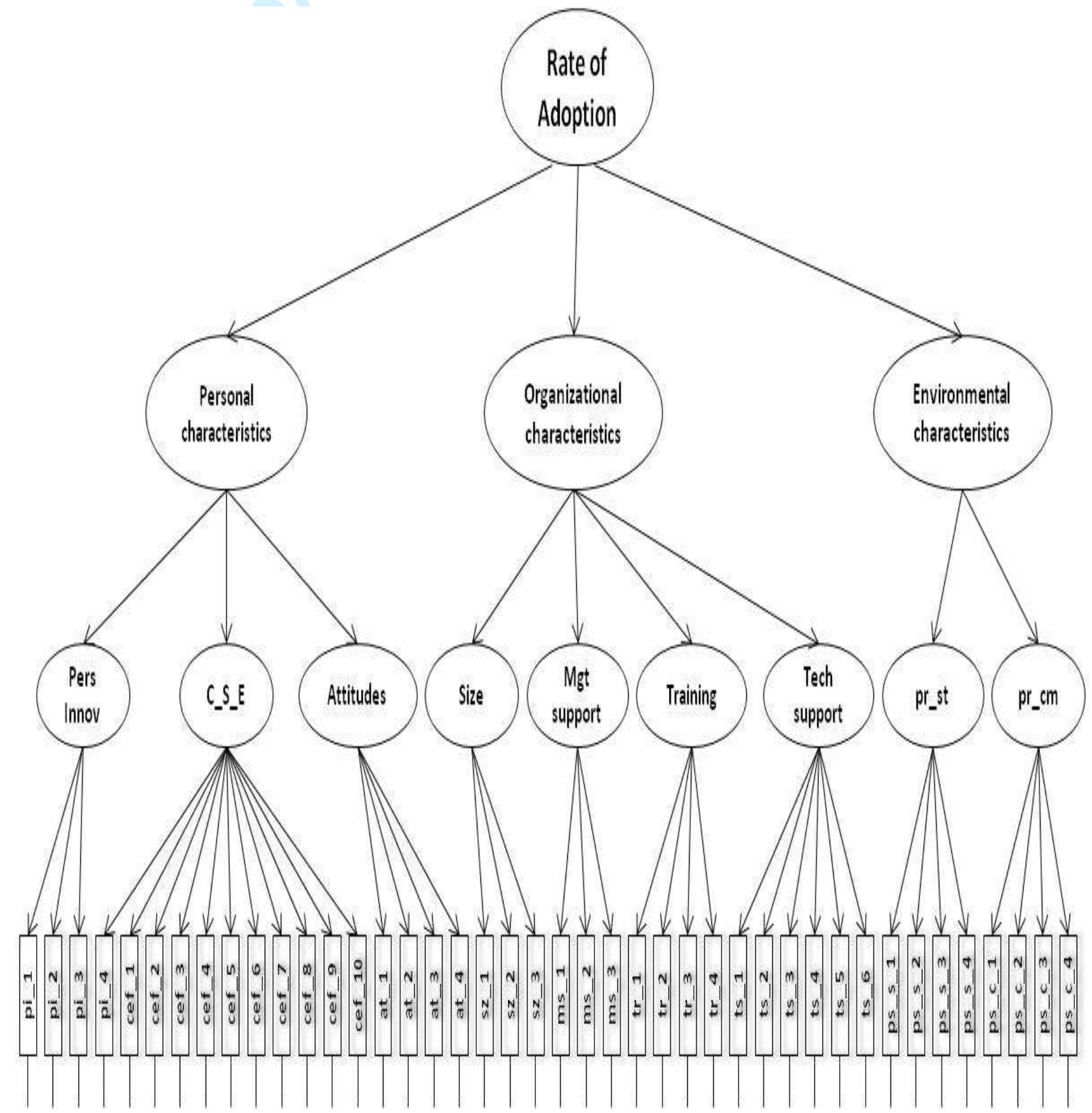


Table 1. Source of Constructs

\begin{tabular}{l|l}
\hline \multicolumn{1}{c|}{ Construct } & \multicolumn{1}{c}{ Source of construct } \\
\hline \hline Personal innovativeness (4)* & $\begin{array}{l}\text { Argawal and Prasad, 1998; } \\
\text { Schillewaert } \text { et al,. 2005 }\end{array}$ \\
\hline Computer self-efficacy (10) & $\begin{array}{l}\text { Compeau and Higgins, 1995; } \\
\text { Venkatesh and Davis, 1996 }\end{array}$ \\
\hline Attitudes and perceptions (4) & Ajzen and Fishbein, 1969 \\
\hline Size (3) & Dholakia and Kshetri, 2004 \\
\hline Top management support (3) & -------- \\
\hline Training support (4) & Panopoulos and Sarri, 2012 \\
\hline Technical support (6) & Panopoulos and Sarri, 2012 \\
\hline Perceived pressures-stakeholders (4) & Panopoulos and Sarri, 2012 \\
\hline Perceived pressures-competitors (4) & Panopoulos and Sarri, 2012 \\
\hline \hline
\end{tabular}


Table 2. Sub-dimensions of E-PR Adoption Construct

\begin{tabular}{|c|c|c|c|c|c|c|c|c|c|c|c|}
\hline $\begin{array}{c}\text { Sub-dimensions of E-PR } \\
\text { Adoption construct } \\
\end{array}$ & Mean & $\begin{array}{c}\text { St } \\
\text { Dev }\end{array}$ & $P I$ & $C \_S \_E$ & $A t t$ & Size & $\begin{array}{l}\text { Mgt } \\
\text { Sup } \\
\end{array}$ & $\operatorname{Trn}$ & $\begin{array}{l}\text { Tech } \\
\text { Sup } \\
\end{array}$ & $\begin{array}{l}\text { Perc } \\
\text { Stkh } \\
\end{array}$ & $\begin{array}{l}\text { Perc } \\
\text { Com }\end{array}$ \\
\hline Personal innovativeness & 5.62 & 1.66 & $0.81 *$ & $0.63 * *$ & 0.58 & 0.44 & 0.54 & 0.61 & 0.48 & 0.38 & 0.42 \\
\hline Computer self-efficacy & 5.58 & 1.71 & & 0.79 & 0.64 & 0.52 & 0.46 & 0.59 & 0.63 & 0.59 & 0.51 \\
\hline $\begin{array}{r}\text { Attitudes and perceptions } \\
\text { of PR practitioners }\end{array}$ & 5.17 & 1.82 & & & 0.87 & 0.38 & 0.55 & 0.6 & 0.58 & 0.52 & 0.55 \\
\hline Top management support & 4.95 & 1.69 & & & & & 0.91 & 0.67 & 0.54 & 0.63 & 0.61 \\
\hline Training support & 4.93 & 1.29 & & & & & & 0.83 & 0.59 & 0.67 & 0.49 \\
\hline Technical support & 5.75 & 1.76 & & & & & & & 0.77 & 0.46 & 0.41 \\
\hline $\begin{array}{r}\text { Perceived pressures - } \\
\text { stakeholder publics }\end{array}$ & 4.29 & 1.36 & & & & & & & & 0.78 & 0.68 \\
\hline $\begin{array}{r}\text { Perceived pressures - } \\
\text { competitors }\end{array}$ & 5.14 & 1.86 & & & & & & & & & 0.76 \\
\hline
\end{tabular}


Table 3.The Structure of E-PR AdoptionMajor Dimensions

\begin{tabular}{|c|c|c|c|c|c|c|c|c|c|c|c|}
\hline \multicolumn{4}{|c|}{ Personal characteristics } & \multicolumn{4}{|c|}{ Organizational characteristics } & \multicolumn{4}{|c|}{ Environmental characteristics } \\
\hline & AVE & $\Phi^{2}<\mathrm{AVE}$ & Rel & \multirow[b]{2}{*}{$\begin{array}{l}\text { Managemen } \\
\text { t Support }\end{array}$} & AVE & $\Phi^{2}<\mathrm{AVE}$ & Rel & \multirow{4}{*}{$\begin{array}{l}\text { Pressures } \\
\text { Stakeholders } \\
\text { Pressures } \\
\text { Competitors }\end{array}$} & AVE & $\Phi^{2}<\mathrm{AVE}$ & Rel \\
\hline $\begin{array}{l}\text { Personal } \\
\text { Innovativeness }\end{array}$ & 0.56 & $\checkmark$ & 0.75 & & 0.57 & $\checkmark$ & 0.79 & & 0.57 & \multirow{3}{*}{$\checkmark$} & 0.86 \\
\hline $\begin{array}{l}\text { Computer } \\
\text { Self-efficacy }\end{array}$ & 0.59 & $\checkmark$ & 0.69 & $\begin{array}{l}\text { Training } \\
\text { support }\end{array}$ & 0.62 & $\checkmark$ & 0.83 & & 0.62 & & \multirow[t]{2}{*}{0.88} \\
\hline $\begin{array}{l}\text { Attitudes and } \\
\text { Perceptions }\end{array}$ & 0.61 & $\checkmark$ & 0.84 & $\begin{array}{l}\text { Technical } \\
\text { Support } \\
\end{array}$ & 0.69 & $\checkmark$ & 0.81 & & & & \\
\hline \multicolumn{4}{|c|}{$\begin{array}{l}\text { GFI 0.931; AGFI0.902; CFI 0.918; RMSEA } \\
0.062\end{array}$} & \multicolumn{4}{|c|}{$\begin{array}{l}\text { GFI 0.911; AGFI0.896; CFI 0.901; } \\
\text { RMSEA } 0.07\end{array}$} & \multicolumn{4}{|c|}{$\begin{array}{l}\text { GFI 0.940; AGFI0.908; CFI 0.90; } \\
\text { RMSEA 0.083 }\end{array}$} \\
\hline
\end{tabular}

AVE= Average Variance Extracted ; $\Phi^{2}=$ the square of the inter-factor correlations between any two constructs; Rel= composite reliabilities 
Table 4. SEM Results of Different Levels of the E-PRAdoption Hierarchical Model

\begin{tabular}{lcccc}
\hline \multicolumn{1}{c}{ Models tested } & GFI & AGFI & CFI & RMSEA \\
& & & & \\
\hline \hline Second order factor model & 0.83 & 0.78 & 0.81 & 0.078 \\
First order factor model & 0.91 & 0.82 & 0.87 & 0.081 \\
\hline \hline
\end{tabular}

